\title{
Greenhouse Effect, Sea Level Rise, and Barrier Islands: Case Study of Long Beach Island, New Jersey
}

\author{
JAMES G. TITUS \\ Environmental Protection Agency \\ Office of Policy Analysis \\ Washington, DC 20460
}

\begin{abstract}
Increasing atmospheric concentrations of carbon dioxide and other gases are expected to cause a global warming that could raise sea level a few feet in the next century. This paper examines four options by which barrier-island communities could respond, focussing on Long Beach Island, New Jersey. For the next few decades, the most common response will probably be to raise the islands in place by pumping sand onto beaches and building lots. Eventually, as costs increase, many communities may accept a gradual landward retreat. Nevertheless, federal agencies that encourage risky development, state agencies that discourage it, residents who feel entitled to subsidized coastal protection, and environmentalists insensitive to constitutional property rights will all have to compromise for a rational solution to be possible. Local officials on barrier islands should begin to hold public meetings to develop a public consensus on the appropriate response to sea level rise.
\end{abstract}

Keywords - barrier islands, New Jersey, sea level rise, greenhouse effect

\section{Introduction}

In the last three decades, the barrier islands of the U.S. Atlantic and Gulf coasts have been transformed from tranquil fishing villages to thriving recreational centers hosting millions of visitors each weekend. With a cool sea breeze and a view of the water, an ocean beach for surfing and sun bathing, a back bay for sailing, skiing, and swimming, and sport fishing in both ocean and bay, barrier islands have something for everybody.

The water that makes these islands desirable, however, also places them at risk. The beautiful homes with their oceanfront views are vulnerable both to storms, which can destroy houses not elevated on pilings, and erosion, which can leave a house standing in the water regardless of its construction. The back bays limit people's ability to escape these problems by simply retreating landward, and during storms they sometimes breach the islands, forming inlets.

These risks could become more severe in the coming decades. The expected global warming from the greenhouse effect is likely to raise sea level a few feet in the next one hundred years and may increase the frequency of severe storms as well. Newspapers and Congressmen from coastal states have pointed out that entire barrier islands would be threatened. Coastal geologists, on the other hand, have expressed the concern that if coastal towns armor their shorelines, they will eventually lose their beaches. Less attention, however, has been paid to two other options, which will probably be more typical of recreational barrier islands: (1) raising islands in place, and (2) helping islands to migrate landward.

The opinions expressed in this article do not necessarily represent official views of the U.S. Environmental Protection Agency. 
In this article, we discuss the likely impacts of future sea level rise on developed barrier islands, focusing on Long Beach Island, New Jersey, as an example. After summarizing previous studies, we present four possible responses; estimate the cost of implementing each of these responses on Long Beach Island; examine the implications for other islands; and discuss whether future sea level rise warrants immediate action.

\section{Climate Change and the Coastal Environment}

Since 1979, there has been a general consensus that a doubling of carbon dioxide would raise global temperatures 1.5 to $4.5^{\circ} \mathrm{C}$, and that such a doubling is likely to occur over the next century (NAS 1979). More recent assessments have pointed out that emissions of methane, nitrous oxide, and numerous other gases that absorb infrared radiation could further increase this warming (Ramanathan et al. 1985), and that warmer temperatures may increase the rate of natural emissions of these gases (Lashoff 1989). Although national policy makers are beginning to formulate strategies to slow global warming, there is an emerging consensus that at least a one or two degree warming is inevitable, due to past emissions and the time it will take to change production practices and retire existing machinery (Seidel and Keyes 1983; Hansen et al. 1985; EPA 1989. $)^{2}$

In the late 1970 s, some scientists suggested that the projected global warming might cause a 20 foot (5 to 7 meter) rise in sea level over the next few decades, due to a disintegration of the West Antarctic Ice Sheet (e.g. Schneider and Chen 1980). However, Hughes (1983) and Bentley (1983) showed that such a deglaciation would take at least 200-500 years. As a result, most recent assessments have focussed on other contributors to future sea level rise: expansion of ocean water and the melting of mountain glaciers and parts of the ice sheet in Greenland. Figure 1 illustrates recent assessments of future global sea level rise, which generally range from 2 to 7 feet (50 to 200 centimeters) by the year 2100; to estimate relative sea level rise for particular locations, one must add or subtract local trends in subsidence or emergence.

The most widely assessed effects of future sea level rise are inundation, erosion, increased flooding, and saltwater intrusion. Many studies have estimated the inundation of dry land that would occur from a rise in sea level, which requires little more than accurate contour information (e.g. Kana et al. 1984; Schneider and Chen 1980). Kana, et al.

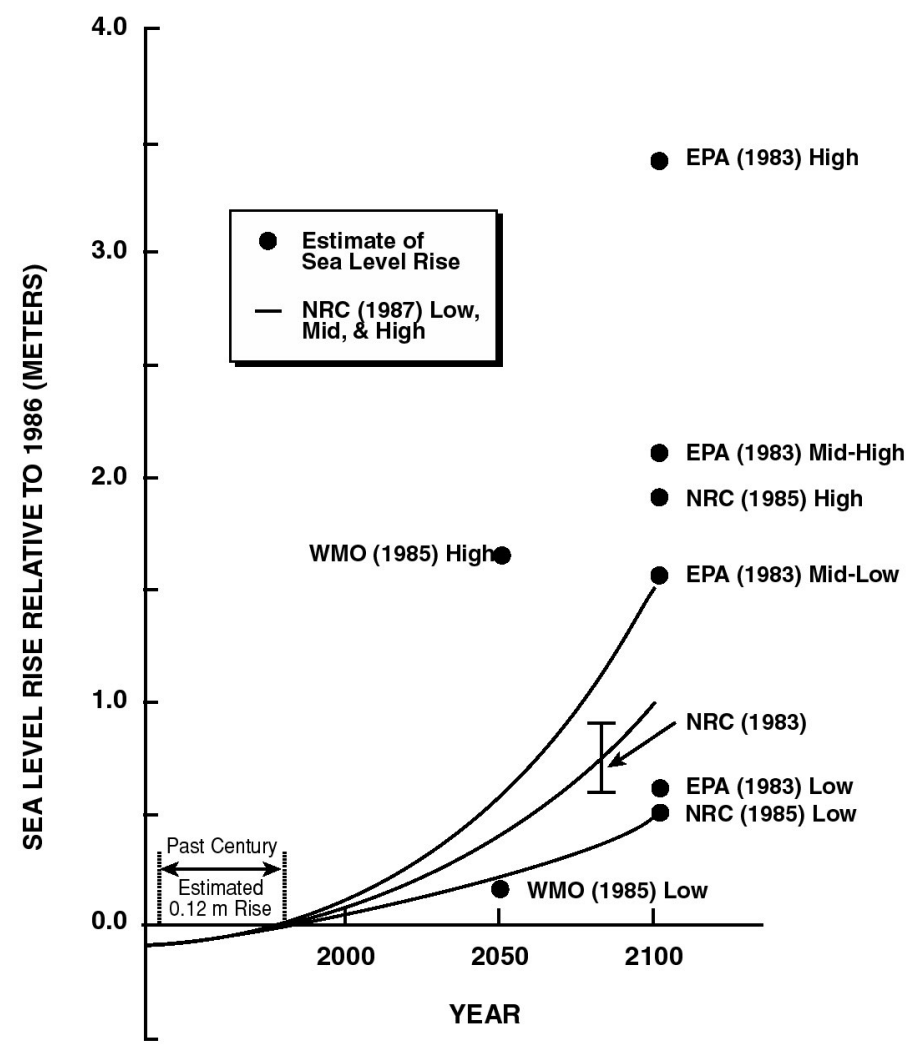

Figure 1. Estimates of future sea level rise. (Glacial volume estimate of NRC (1985) augmented with thermal expansion estimates of NRC (1983).)

Sources. Environmental Protection Agency, Projecting Future Sea Level Rise, 1983. National Research Council, Responding to Changes in Sea Level: Engineering Implications, 1987. National Research Council, Glaciers, Ice Sheets, and Sea Level, 1985. National Research Council, "Probable Future Changes in Sea Level Resulting From Increased Atmospheric Carbon Dioxide," Changing Climate, 1983. World Meteorological Organization, International Assessment of the Role of Carbon Dioxide and Other Greenhouse Gases in Climate Variations and Associated Impacts, 1985. 
(1988) surveyed elevations to estimate possible wetland loss in the areas of Charleston, S.C. and Long Beach Island, New Jersey. Park, et al. $(1986,1989)$ used topographic maps and remote sensing and estimated that a two- to seven-foot rise in sea level would result in a 50-90 percent loss of U.S. wetlands. We have argued elsewhere that adverse environmental impacts could be diminished significantly if the area inland of the wetlands are abandoned to enable ecosystems to migrate landward (Titus 1984, 1986, 1988).

Although erosion is more difficult than inundation to predict, applications of the Bruun (1962) rule and other simplified procedures suggest that a one-foot rise in sea level would erode the shore 50-100 feet in New Jersey (Kyper and Sorensen 1985) and Maryland (Everts 1985); 100-200 feet in South Carolina (Kana et al. 1984); 200-400 feet in California (Wilcoxen 1986); and 100-1000 feet in Florida (Bruun 1962). Flooding would increase both because storm surges would have higher bases to build upon (Kana et al. 1984; Leatherman 1984) and because rainwater would drain more slowly (Titus et al. 1987). Finally, the salinity of estuaries and aquifers would increase, threatening water supplies and aquatic life. (e.g. Hull and Titus 1986; Williams 1989).

Other effects of global warming may exacerbate these impacts. Warmer temperatures could increase the frequency and severity of hurricanes 50 percent (Emmanuel 1988), increasing both erosion and storm damage. Although there is a general consensus that average annual rainfall will increase, many researchers expect precipitation to become more variable (e.g. Rind et al. 1989), which would imply dryer droughts and wetter rainstorms, amplifying both salinity and flooding problems.

\section{Impacts on Barrier Islands}

If human activities do not interfere, a barrier island can respond to sea level rise by either (1) washing over landward and remaining intact, or (2) breaking up and drowning in place. Figure 2 provides a cross section of a barrier island washing over: the island erodes from the ocean side until it reaches a critical width, generally about 400-700 feet (Leatherman 1979), after which the erosive forces of storms tend more to push sand landward onto the bay side of the island. The net effect of the washover process is similar to rolling up a rug; as the island rolls landward, it builds upward and remains above sea level. By contrast, Figure 3 illustrates the fate of Isle Dernier in Louisiana (Penland et al.), which was unable to keep up with the (subsidence-induced) relative sea level rise of three feet per century.

Coastal geologists are not yet able to forecast whether a particular island will break up or wash over, although island disintegration appears to be more frequent in areas with high rates of relative sea level rise. For developed islands, however, the distinction between washover and breakup is largely academic: Most are much wider than the critical width necessary to permit island migration, and thus the islands would both erode from the ocean side and in many cases be inundated from the bay side. Moreover, development tends to impede
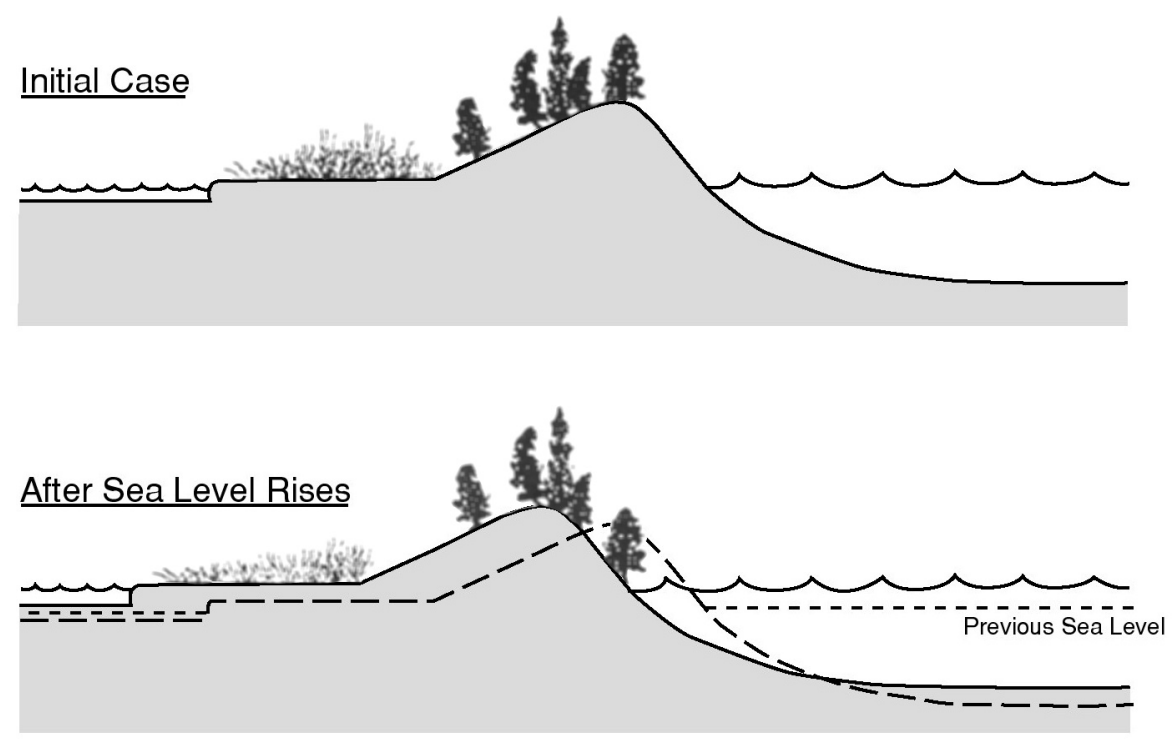

Figure 2. Overwash: natural response of undeveloped barrier islands to sea level rise. 
landward migration: structures block the landward transport of sand, and after storms deposit sand onto the streets, local public works departments generally bulldoze it back onto the beach, rather than allowing it to blow or wash to the bay side. Thus, even islands narrow enough to migrate landward under natural conditions may become narrower if there is no explicit decision to hold back the ocean or fill part of the bay.

Allowing nature to take its course, however, is only one of four options that policy makers could consider. Other options include artificially assisting a
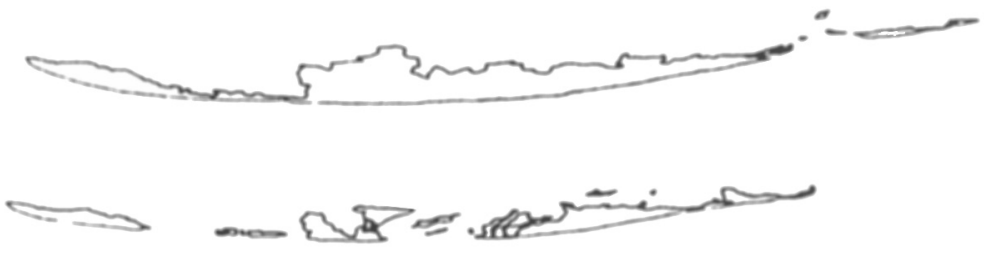

1956

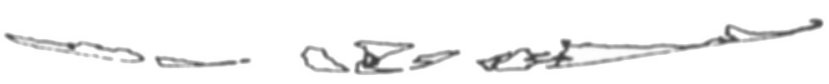

1978
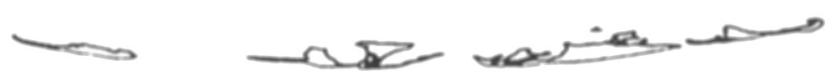

1988
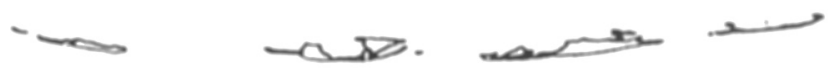

Figure 3. The breakup of Isle Derniere, Louisiana (now Isles Dernieres). Source. Louisiana Geological Survey.

landward migration, raising the island in place, and encircling it with a levee. Figure 4 illustrates all four options, which we now examine in detail. (Although motivated by the prospect of global warming, many of the issues discussed below would eventually emerge even with current trends in erosion and sea level. $)^{3}$

\section{No Coastal Protection}

For the first few feet of sea level rise, oceanside erosion would be a greater concern than inundation, as it is today. In many communities, the recreational beach would be the first casualty; because floodplain regulations generally require oceanfront structures to be built on pilings sunk well into the sand, many houses and hotels would continue to stand as the beach narrowed; a stroll along the beach would require one to walk under oceanfront houses or navigate around buildings flush against the high-water mark. Eventually, the structures would become uninhabitable and have to be removed; but a few extra years of use would often justify maintaining them, at least from the perspective of the property owners.

From the social perspective, however, it probably would be better to remove oceanfront structures. The beach is a critical asset and often worth more to the community than the oceanfront houses, since a large part of the value of coastal property results from a nice beach being within walking distance. To retain this asset, communities may require structures to be removed as soon as they are seaward of the vegetation line, a policy already embodied in Texas' Open Beaches Act and Maine's Dune Rules. Even so, recreational use of the beach would be somewhat impaired in the time it took to condemn property and remove the structures.

To delay the day when erosion leaves the front row of houses standing on the beach, two approaches already being considered by coastal states may prove useful: setbacks and post-disaster plans. Nine states currently require new construction to be set back by the erosion expected over the next 30 to 60 years (OCRM 1989). ${ }^{4}$ In North Carolina, hotels and apartments must be set back farther than single-family houses because the latter are presumed moveable. Post-disaster plans that prohibit reconstruction of severely damaged ocean front property have long been proposed by state coastal zone officials; but such provisions have usually met stiff public opposition, and have rarely been implemented so far. ${ }^{5}$

Both of these policies are somewhat at odds with the free-market philosophy, which holds that if people want to risk their own money on a risky investment, that is their own concern, not the government's. However, on U.S. barrier islands, people are not simply risking their own money: (1) Because the National Flood Insurance Program will compensate homeowners for storm losses, other 
policy holders--and ultimately federal taxpayers--are at risk; ${ }^{6}$ (2) if a house is built strongly enough to withstand sea level rise, the publicly owned beach is at risk; and (3) structures can interfere with the ability of dune ecosystems to migrate landward (at least in areas where they have not already been destroyed.)

At the national level, another option for encouraging a retreat would be to deny federal flood insurance to new and rebuilt structures along the ocean front. ${ }^{7}$ Such a policy would be more consistent with the free-market philosophy in that the government would not be dictating investment decisions. However, the extent to which such a policy would discourage construction is unclear: People were building along the coast before the program was created; given the
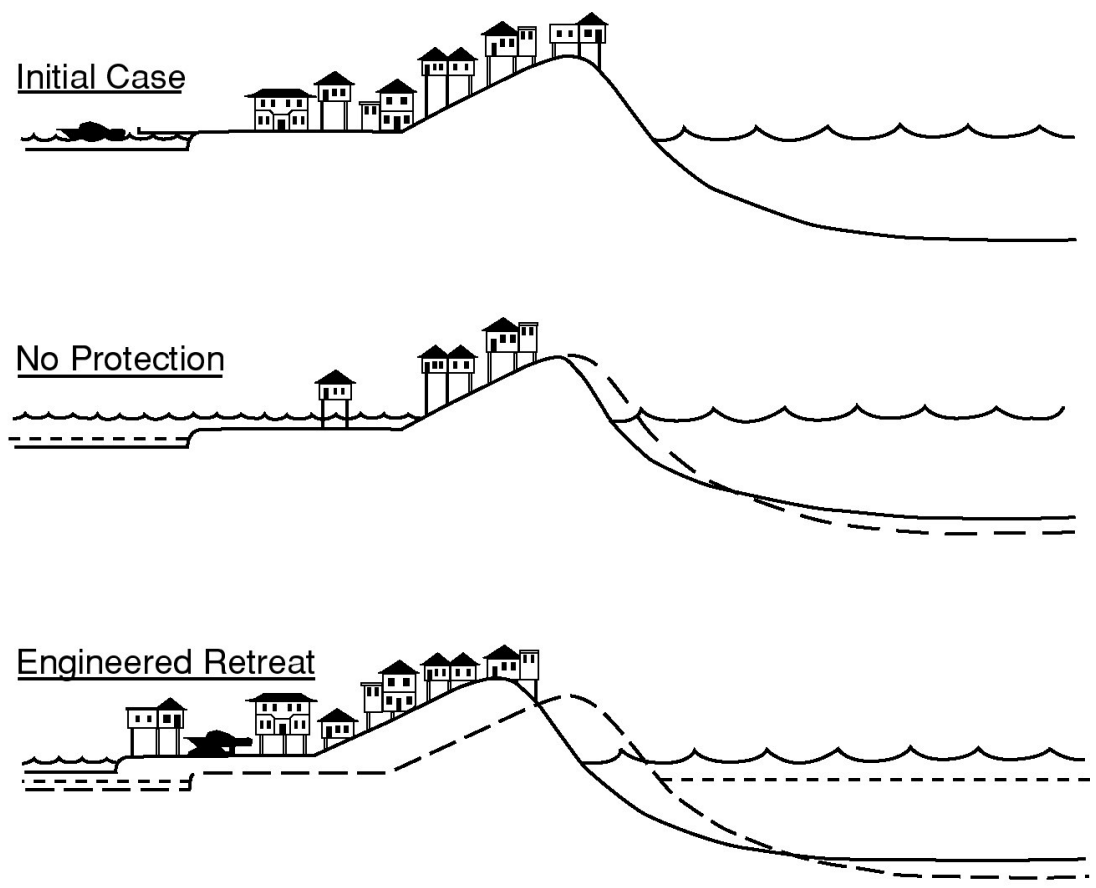

high rents that seaside cottages command, many investors would choose to rebuild even without insurance.

Regardless of changes in the flood insurance program, post-disaster reconstruction bans could become increasingly important as sea level rises. However, by definition, this

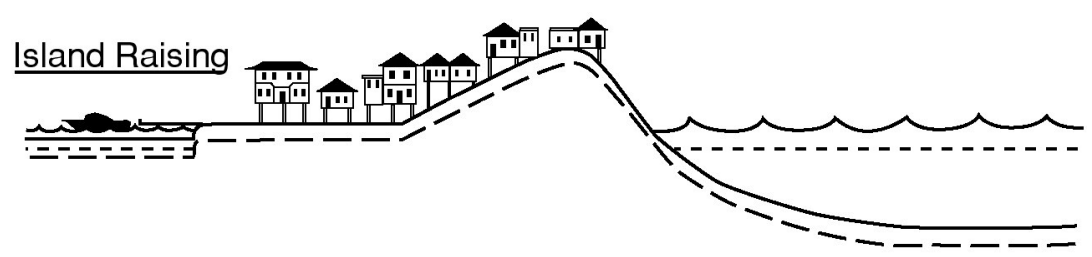
policy implies that buildings are lost to the sea; it merely keep the same property from being lost twice. By contrast, setbacks may become less useful: Most of the coast will already be developed; but even for the remaining undeveloped areas, accelerated sea level rise implies that a setback of a given distance will protect property for a smaller number of years. Increasing the required setbacks would be difficult: They have been legally and politically feasible primarily because lots have usually been deep enough and erosion slow enough to permit development on the properties to which they apply. Hotel owners, for example, do not like having to put parking lots on the seaward sides of the buildings, but at least the hotel is built. Tripling or quadrupling required setbacks, by contrast, would effectively prevent any construction on most oceanfront lots, rendering them worthless.

Even if larger setbacks pass legal challenges, they would often be economically inefficient. The rents from oceanfront property are usually sufficient to recover the cost of the structure within five to ten years; hence it would be completely rational to build a house even if one was certain it would be destroyed ten years later. In this context, a rigid setback policy would be a "Catch-22" in which the government tells 
private property owners: "We realize that the rational solution would be for you to build now and tear the structure down ten years hence, but since we can not force you to tear the house down in the future we will not let you build now."

This line of reasoning assumes that developing the ocean sides of barrier islands was reasonable in the first place, an assumption that is generally accepted by property owners and barrier-island townships. People concerned about endangered sea turtles and shore birds, however, have suggested that some barrier islands probably should never have been developed--at least on the ocean sides. From this perspective, sea level rise presents an opportunity to make economic and ${ }^{9}$ public-safety arguments for creating a buffer zone between the primary dune and the first row of houses (Pilkey et al. 1981; Howard et al. 1985).

If applied indefinitely, a policy of no coastal protection would eventually lead people to abandon most barrier islands. As the case study of Long Beach Island illustrates, such an abandonment would be expensive. Moreover, the environmental impacts would not always be negligible: If the islands break up, ocean waves would enter the estuary, eroding wetlands rapidly; in Louisiana, the risk of wetland erosion has already been a primary motivation for state and local efforts to fortify even undeveloped islands. (Louisiana Wetlands Protection Panel 1987). Even if the islands do not break up, their landward migration could rapidly narrow back bays.

Perhaps more importantly, the people who inhabit barrier islands might continue to visit the beach. Constructing alternative housing on the mainland could increase the difficulty of abandoning coastal lowlands to allow wetlands to migrate inland. Moreover, if people commute by car, today's Sundayafternoon congestion would become a daily affair, perhaps necessitating more roads and bridges. If the commute is by boat, channels would have to be dredged and wetlands filled to accommodate the ferry traffic.

\section{Engineering a Retreat}

Although developed barrier islands would not naturally migrate landward in their entirety, it would often be possible to engineer a retreat that imitates natural overwash, by creating new land on the bay side as the ocean side erodes. Compared to the value of property on barrier islands, the cost of filling in a new lot every few decades on the bay side is minimal: Until environmental regulations put a stop to the practice, the favorable economics led many developers to fill bay sides, the most extreme example being Coney Island, New York, which is no longer an island.

Even though an engineered retreat imitates natural processes, the landward migration would be somewhat slower. Coastal geologists generally recognize that islands in overwash mode migrate landward more rapidly than eroding ocean shorelines. In the former case, sand is both washed offshore and washed or blown to the bay side; in the latter case, sand is only washed offshore, resulting in a slower retreat of the shoreline. ${ }^{8}$

To truly duplicate the overwash process, an engineered retreat would involve pumping sand directly from the beach to the bay sides, unacceptably accelerating beach erosion. A more plausible approach would be to import sand from a few miles offshore, ${ }^{9}$ resulting in landward migration equal to the oceanside erosion rate.

An engineered retreat would require existing prohibitions of bayside filling to be modified to account for sea level rise. Although this option is motivated by the desire to work with nature, one can anticipate that at least initially, some environmentalists will be skeptical. Those who would like to see barrier islands abandoned would oppose any action to maintain their economic viability; and some who accept the principal of development would still feel that the environment is being unreasonably sacrificed. From the narrow perspective of the marshes or shallow waters that must be filled to accommodate landward migration, the environment would be compromised.

From the broader perspective, however, engineered retreat is probably the least disruptive response-the entire system merely shifts landward as ocean displaces beach, which displaces housing, which displaces estuary, which displaces mainland development. Pragmatists may thus ${ }^{10}$ conclude that it is more 
important to ensure that mainland areas are abandoned to allow wetlands to migrate inland. (See Titus 1989 for a description of options for enabling wetlands to migrate landward.) Nevertheless, in Miami, New York, Charleston and other areas where cities lie behind barrier islands, it may not be feasible for the mainland to yield land to the estuary; the environmental acceptability of retreat would thus depend on whether the bay is wide enough to accommodate narrowing a few hundred feet per century. Although the narrowing could be even worse if the island is abandoned, ${ }^{10}$ it could be avoided for the two remaining options, as we discuss below.

Because the no-protection and engineered-retreat options both involve an eroding ocean shoreline, many of the implications would be similar. One advantage of the latter approach is that there would be vacant land to which threatened ocean-side structures could be moved, increasing the political feasibility of creating oceanside buffers. However, under current conventions in many states, newly created land would belong to the bay-side property owners, which would usually not be the same people as the oceanside owners. ${ }^{11}$ One can envision a number of mechanisms by which states and localities might address this land-ownership issue. In cases, where newly created land belongs to the bayfront owner, the owner may voluntarily sell the new lot to a formerly-oceanside owner, or take possession of the new bayfront lot and sell the old lot. If the bayfront owners chose not to sell, governments might choose to purchase the rights to newly-created land through eminent domain, compensating the bayfront owner for both the loss of shorefront and the new lot; the ability to compel a sale might motivate bayfront owners to simply take the new lot and sell the old lot.

The ability of existing legal conventions to accommodate a retreat is uncertain, having never been tested. Even if a governmental taking is compensated, and hence legal under the $5^{\text {th }}$ amendment of the U.S. constitution, it would also have to be legal under state constitutions, which vary in their definition of what is and what is not a sufficiently legitimate governmental activity to permit eminent domain acquisitions. With the long-term survival of the island at stake, courts in some states would probably view coastal protection as legitimate; in other states, constitutions may have to be amended.

Even where a retreat would be feasible under existing laws, institutional changes would often be desirable. Under the preceding scenarios, every time a new lot was created, the government would have to negotiate with bayfront owners for the purchase of more land. Under some scenarios, the bayfront house would be moved periodically. In the case of yacht clubs, marinas, and other waterfront businesses, this situation may be unavoidable. Nevertheless, for other parts of the island, this problem could be minimized by uncoupling the right to newly formed land from the ownership of property that happens to be on the bay side. For example, governments might create a system of transferable development rights in which one could fill and build on a bay side lot provided that an equally large structure on the ocean side was removed. Although such a system would probably require compensation, costs could be relatively small if the effective date was 50-100 years hence. ${ }^{12}$ (We discuss this approach for enabling wetlands to migrate inland elsewhere; see Titus (1986, 1989).

An engineered retreat would probably raise more political and legal problems than the other responses. Although these problems do not seem insurmountable, we suspect that will be overcome only in cases where the economic or environmental costs of other options are ${ }^{11}$ unacceptable. The Long Beach Island study, below, suggests that this could happen by 2075 .

\section{Raising An Island In Place}

To residents who want to "keep things the way they are," the most appealing option is to simply elevate the island in place. Initially, while erosion is the primary concern, sand can be pumped onto the beach (including the underwater part of the beach profile). Later, as property becomes threatened with inundation, roads and lots can be elevated as well. Older houses can be elevated; newer houses already above the 100-year flood level could be left alone, at the price of a gradual increase in flood risk, until the increased risk warranted further elevation.

This option avoids all the institutional problems of the no-protection and engineered retreat scenarios. No one is prohibited from building or rebuilding; no one has to move their house; the 
government does not have to spend time buying and selling property; neighbors do not become jealous of one another as some gain and others lose their views of the water. Governmental policies do not create classes of winners and losers.

The greatest problem with this option is probably its cost. Raising islands would require greater dredging expenditures than island migration: (1) Because the entire island and underwater profile must be raised, it requires more sand, particularly on wide islands; and (2) although most types of sand would be suitable for bayside filling and elevating building lots, the sand placed on the beach profile would have to be compatible with the current beach. ${ }^{13}$

Environmentalists opposed to bayside filling might prefer this option. However, the eventual impact on wetlands could be worse. Bays would become deeper and wider, increasing wave erosion of wetlands. ${ }^{14}$ Moreover, stabilizing barrier islands in their current locations would tend to encourage mainland property owners to stabilize those shorelines and thereby block the landward migration of wetlands. Finally, because raising an island would require more sand than an engineered retreat, there would be a greater disruption of marine life inhabiting areas around the offshore sand deposits.

\section{Encircling the Island with Levees (Dikes)}

Over the last few centuries, the most common approach for protecting developed areas from rising sea level (and land subsidence) has been to construct dikes or levees to hold out the sea and install pumping systems to remove rainwater and water that seeps through these earthen walls. About half of the Netherlands is protected from the sea in this fashion, as well as parts of river deltas in China, Belgium, and Louisiana. Many other areas that are above sea level employ levees to prevent flooding. Thus far, only the Dutch have encircled barrier islands with levees.

Like raising barrier islands, this approach does not require major institutional changes. Except for the properties that must be abandoned to make room for the levee, the direct physical interference with a community is even less, since roads, houses, and lots need not be raised. The beach can also be maintained, provided that the community is willing spend the additional resources necessary to import sand from offshore.

For the typical recreational barrier island, however, a levee would interfere with the way of life more than either retreat or raising the island because people would lose their views of the waterfront, particularly the bay. Windsurfers and sailboat racers would face the additional ${ }^{12}$ nuisance of hoisting their boats over the levee every time they wanted to go for a sail, and some people would be unable to climb the steps. People could still walk along the levee, but "it just wouldn't be the same." Although these considerations might strike some people as trivial, aesthetics are very important for resorts.

Levees would also face some practical obstacles. While island raising and migration can be implemented incrementally as the sea rises, the encirclement option would require a large lump-sum expenditure because of the cost of installing a pumping system, land acquisition, and the initial levee. Moreover, the system would have to be over-designed because with a barrier island largely below sea level, a breach in the levee during a storm could form an inlet in the middle of the island. Finally, unit costs would be much higher for narrow barrier islands than for most other low regions because relatively little land would be protected for each mile of levee. Nevertheless, this option may be appropriate for wide, urbanized islands where the view of the bay is a relatively unimportant part of people's lives and raising the island would require an inordinate amount of sand.

The adverse impacts of deeper estuaries associated with island raising would apply with levees as well. One possible advantage over other options is that the pumping system would keep the water table lower and hence avoid the inundation of septic tanks. A possible disadvantage would be interference with sea turtles and other animals that half to walk across the island. However, islands sufficiently urban to justify levees would usually have neither septic systems nor sea turtles. 


\section{Case Study of Long Beach Island, New Jersey}

Although the preceding discussion suggests that raising barrier islands would be less disruptive than other options, it does not tell us how the costs compare for the various options. To gain a first order understanding of the relative costs of these options, we examined Long Beach Island, New Jersey, drawing on papers by Leatherman (1989), a coastal geologist; Weggel et al. (1989), coastal engineers; and Yohe (1989), an economist.

Figure 5 illustrates Long Beach Island, 15 miles north
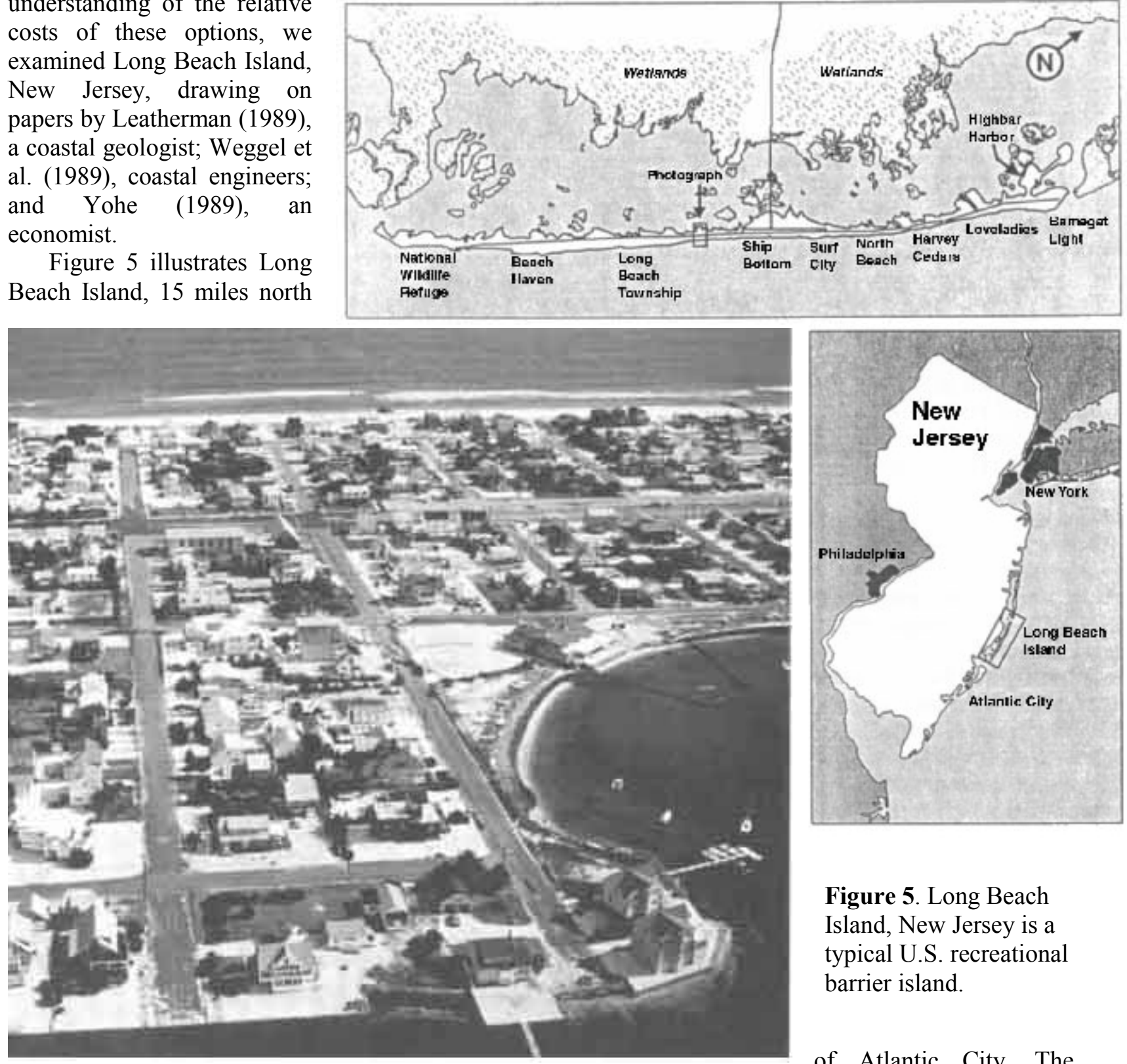

Figure 5. Long Beach Island, New Jersey is a typical U.S. recreational barrier island.

island is 18 miles long, and generally two to four blocks wide. Over 95 percent of the structures are single-family houses. The only buildings with more than two stories are the Barnegat Lighthouse, a few dozen houses built at the turn of the century, and a few three-story hotels. With the exception of the strip between Surf City and Barnegat Light, the south end of the island, and High-Bar Harbor, the island was mostly developed before 1960, and hence, few houses are elevated above flood levels. The 1962 Ash Wednesday storm cut an inlet in Harvey Cedars, and destroyed many houses at the south end of the island. 
Given that we could examine only one island in-depth, Long Beach Island seemed to be a suitable site. Densely developed with single-family houses on $50 \times 100$ to $100 \mathrm{X} 200 \mathrm{ft}$ lots, it typifies many islands along the Gulf and Atlantic coasts and represents a rough compromise between islands populated with high-rise buildings and the lightly developed islands of the southeast. ${ }^{13}$

Our examination of Long Beach Island involves estimating (1) the necessary quantities and costs of sand, (2) engineering costs of moving structures, rebuilding infrastructure, and building levee and pumping systems; and (3) the value of the property that would be lost if shores were not protected. We discuss each in turn.

\section{Sand}

Table 1 illustrates our estimates of the necessary quantities of sand for the island-raising and retreat scenarios. Most of the sand required for raising the island would be used to nourish the beach. Our estimate is based on the assumption that the entire beach profile extending out to the 30 -foot contour (including tidal shoals) would have to be raised by the amount of sea level rise. ${ }^{15}$ We caution that this assumption provides an estimate of the sand that would eventually be required after the profile has a few decades to reestablish equilibrium. Leatherman (1989) notes that the profile extends only about half as far if one assumes no storm more severe than the one-year storm; hence, it would probably be possible to delay about half the dredging implied by these estimates for a decade or so.

About 60 percent of the island is below the $5 \mathrm{ft}$ (NGVD) contour, ${ }^{16}$ which is only about 2 feet above high tide. We assume that after the first foot of sea level rise, these low areas would be raised with sea level. For areas above the 5-ft contour, we assume that fill would be brought in only after the sea had risen three feet. This assumption is somewhat arbitrary: many ocean-side lots have an elevation of 10 feet and would hence still be well above sea level. However, the 10-foot NGVD contour is only 9-1/2 feet above current sea level, and with a four foot rise would be only 2-1/2 feet above spring high tide. Such a low ocean side would greatly increase property damage and the risk of an inlet breach during severe storms, and probably would not be ${ }^{14}$ tolerated.

Table 1

Required Sand for Engineering a Retreat or Raising Long Beach Island in Place (millions of cubic yards)

\begin{tabular}{cccccc}
\hline Retreat & \multicolumn{3}{c}{ Raising Island } & \\
\cline { 1 - 4 } $\begin{array}{c}\text { Sea Level } \\
\text { Rise (ft) }\end{array}$ & & $\begin{array}{c}\text { Beach } \\
\text { Profile }\end{array}$ & $\begin{array}{c}\text { Bay } \\
\text { Side }\end{array}$ & $\begin{array}{c}\text { Ocean } \\
\text { Side }\end{array}$ & Total \\
\hline 1 & 5.8 & 15.6 & - & - & 15.6 \\
2 & 11.7 & 31.3 & 4.6 & - & 35.9 \\
3 & 17.6 & 46.9 & 9.2 & - & 56.1 \\
4 & 23.4 & 62.6 & 13.7 & 3.1 & 79.4 \\
5 & 29.3 & 78.2 & 18.3 & 6.1 & 102.6 \\
6 & 35.2 & 93.9 & 22.9 & 9.2 & 126.0 \\
7 & 41.0 & 109.6 & 27.5 & 12.2 & 149.3 \\
8 & 46.8 & 125.1 & 32.1 & 15.3 & 172.5 \\
\hline
\end{tabular}

Source: Weggel et al. (1989): Retreat.

Other estmates derived from geographic data reported in Weggel et al. (1989), see text.

For the retreat scenario, we use estimates from Weggel et al. (1989). Note that these estimates are almost equal to the non- profile sand requirements for raising the island. Both protection options involve raising the existing parts of the island, and the additional sand required to create new land in the retreat scenario approximately balances the savings from not having to raise the ocean-side lots that erode. 
Table 2 illustrates our estimates of the cost of dredging the necessary sand. We use Weggel's assumption that sand appropriate for raising existing land and creating new land could be obtained for $\$ 5$ per cubic yard. However, because the ocean side would require sand with a suitable grain size, the unit cost would probably increase as least-cost supplies are exhausted. Because no one has estimated the cost of mining all the deposits that would be necessary for a large rise in sea level, we used a cost function Leatherman had estimated for Florida, and scaled it to reflect the difference in current costs between New Jersey and Florida.

Table 2

Costs of Retreat or Raising Long Beach Island in Place

(\$millions)

\begin{tabular}{|c|c|c|c|c|c|c|c|c|c|}
\hline \multirow{3}{*}{$\begin{array}{c}\text { Sea Rise } \\
(\mathrm{ft})\end{array}$} & \multicolumn{5}{|c|}{ Retreat } & \multicolumn{4}{|c|}{ Raising Island } \\
\hline & \multicolumn{2}{|c|}{ Houses } & \multirow[b]{2}{*}{ Sand } & \multirow[b]{2}{*}{ Utilities } & \multirow[b]{2}{*}{ Total } & \multicolumn{2}{|c|}{ Sand } & \multirow[b]{2}{*}{$\begin{array}{c}\text { Raise } \\
\text { Houses }\end{array}$} & \multirow[b]{2}{*}{ Tota } \\
\hline & Raise & Move & & & & $\begin{array}{l}\text { Raise } \\
\text { Profile }\end{array}$ & $\begin{array}{l}\text { Raise } \\
\text { Land }\end{array}$ & & \\
\hline 1 & - & 4 & 29 & 8 & 41 & 105 & - & - & 105 \\
\hline 2 & 7 & 15 & 58 & 29 & 109 & 255 & 23 & 7 & 285 \\
\hline 3 & 14 & 25 & 88 & 51 & 178 & 462 & 46 & 14 & 522 \\
\hline 4 & 22 & 36 & 117 & 72 & 247 & 681 & 84 & 21 & 786 \\
\hline 5 & 22 & 47 & 146 & 93 & 308 & 900 & 122 & 26 & 1048 \\
\hline 6 & 22 & 58 & 176 & 115 & 371 & 1119 & 160 & 31 & 1310 \\
\hline 7 & 22 & 68 & 205 & 136 & 431 & 1339 & 199 & 36 & 1574 \\
\hline 8 & 22 & 79 & 234 & 157 & 492 & 1558 & 237 & 40 & 1835 \\
\hline
\end{tabular}

Source: Cost of Beach fill derived from data supplied by Leatherman.

Cost of elevating land, structures, and rebuilding utilities derived from unit cost estimates supplied by Weggel et al. (1989)

\section{Structures}

Table 2 also illustrates the nonsand costs of the retreat and island-raising scenarios. We use Weggel's estimates of the cost of moving houses ( $\$ 10,000$ per house) from the ocean to the bay side, as well as the number that must be moved. In both scenarios, we assume that half the structures on the bay side would be elevated (implying that the other half will already be elevated). In the island raising scenario, we also assume that half the ocean-side houses would be elevated, using Weggel's estimate of $\$ 5,000$; in the retreat scenario, all these houses would be moved.

Our estimate for the cost of rebuilding infrastructure in the retreat scenario assumes that the amount of roads and utilities built on the newly created land, as a fraction of current road mileage, will be equal to the percentage of houses moved; using Weggel's estimates, this works out to $\$ 20,000$ per house moved. In both scenarios, we ignore the cost of rebuilding infrastructure on parts of the island that are elevated. Water mains and sewers would remain functional, while roads and telephone poles would probably be rebuilt anyway. Although this assumption probably understates the actual cost, the bias applies to both options and hence should not undermine our ability to compare them.

We also use Weggel's estimate that a levee and drainage system could be constructed for $\$ 330$ million. In addition, we assume that a recreational beach would be maintained. Because the levee would provide storm protection, we assume that the recreational beach is designed only for a one-year storm, which would require only half as much sand as nourishing the profile in the island raising scenario. 


\section{Property that Would Be Lost in the No-Protection Scenario}

The cost of not holding back the sea includes property lost to inundation, erosion, and storms. We omit the latter calculation because (1) it would require an extensive modeling effort; (2) most storm losses eventually show up as losses due to erosion and inundations; and (3) damages would be about the same for all but the levee options. We use Weggel's estimates of inundation (based on topographic maps) and erosion (based on the Bruun Rule).

The assets that would be lost from a rise in sea level can be broadly classified as (1) private land, (2) structures, (3) the beach, and (4) public land and infrastructure. Yohe (1989) assumed that the latter category is fully reflected in property values and thus focused only on the first three categories. He sampled twenty strips, each one block wide extending from ocean to bay, and adjusted Ocean County tax maps to reflect current prices for private land and structures. Because the loss of an ocean front lot would (temporarily) increase the value of the next house back, he estimated the ocean-front premium and netted it out.

Given the absence of data on the value of the beach, we had to make an assumption based on our thirty-five summers on the island. The beaches at Long Beach Island are rarely crowded, so we assumed that as long as there was still at least forty feet of beach, there would be no significant diminution of recreational value. However, because many states have enacted policies requiring structures to be torn down once they are seaward of the vegetation line (e.g., Texas Open Beaches Act), we assumed that the value of the beach must be greater to society than the value of a structure. Therefore, once the beach narrowed to forty feet, we included the value of the oceanfront structure as part of the costs. This assumption can be interpreted either as implying that the government would require structures to be torn down or that they would remain standing but cause an inconvenience to the community as great as their fair market rental values. ${ }^{17}$ (On islands with sea turtles or other important life along the dunes or the beach, one should assume a much larger buffer.)

\section{Results}

Table 3 illustrates the cumulative and incremental costs of sea level rise for the four policy options. These results suggest that for the first foot of sea level rise, the cost of holding back the sea would be greater than the value of structures threatened. This result does not imply, however, that it would be rational to allow homes to tumble in the sea. Instead, it reflects the fact that much of the island has a beach (and dune system) sufficiently wide to accommodate a one foot rise in sea level without threatening any structures.

For a rise of two feet or more, the cumulative cost of protection for any of the options would be less than the value of the property lost if there is no coastal protection. Moreover, comparing cumulative protection costs to lost property understates the economic viability of protection. Because a typical realestate investment has a payback period of a decade, the viability of protection is better approximated by comparing property values with the protection costs by decade, or alternatively, annual costs with the annual rental value of property. Over the course of a century, total rental value would generally be about ten times the market value of the property, that is, $\$ 20$ billion. Because protection costs would be under $\$ 1$ billion even for a 5-ft rise, the only relevant question is how, not whether, to protect Long Beach Island.

Although the cumulative costs of a levee system would be somewhat less than the cost of raising the island (at least for a rise greater than $3 \mathrm{ft}$ ), the economics do not seem compelling. From the perspective of financing, a levee would be more difficult to afford than raising the island: A levee would require the community to secure an amount of capital equal to $\$ 26,000$ per house, while island raising could be implemented gradually for a few hundred dollars per house per year. A levee would almost certainly reduce the value of the typical home by a few thousand dollars, suggesting that even a federally subsidized levee would be a questionable proposition. 
Table 3

Cost of Sea Level Rise for Four Alternative Options

\begin{tabular}{|c|c|c|c|c|c|}
\hline \multicolumn{6}{|c|}{ Total Cost } \\
\hline SLR & $\begin{array}{c}\text { Levee with } \\
\text { Beach }\end{array}$ & $\begin{array}{l}\text { Raise } \\
\text { Island }\end{array}$ & $\begin{array}{l}\text { Island } \\
\text { Retreat }\end{array}$ & $\begin{array}{c}\text { No } \\
\text { Protectiol }\end{array}$ & \\
\hline 1 & 52 & 105 & 41 & 55 & \\
\hline 2 & 434 & 285 & 109 & 462 & \\
\hline 3 & 509 & 522 & 178 & 843 & \\
\hline 4 & 584 & 786 & 247 & 1548 & \\
\hline 5 & 687 & 1048 & 308 & 1740 & \\
\hline 6 & 790 & 1310 & 371 & 1932 & \\
\hline 7 & 900 & 1574 & 431 & total loss & \\
\hline 8 & 1010 & 1835 & 492 & total loss & \\
\hline \multicolumn{6}{|c|}{ Incremental Cost } \\
\hline & Levee with & & Raise & & No \\
\hline & Beach & & Island & Migrate & Protection \\
\hline & Levee & Sand & & & \\
\hline 1 & 0 & 52 & 105 & 41 & 55 \\
\hline 2 & 330 & 52 & 180 & 68 & 407 \\
\hline 3 & 0 & 75 & 237 & 69 & 381 \\
\hline 4 & 0 & 75 & 264 & 69 & 705 \\
\hline 5 & 0 & 103 & 262 & 61 & 190 \\
\hline 6 & 0 & 103 & 262 & 61 & total loss \\
\hline 7 & 0 & 110 & 262 & 61 & total loss \\
\hline 8 & 0 & 110 & 258 & 61 & total loss \\
\hline
\end{tabular}

Source: Weggel et al. (1989): Levee Cost.

Yohe (1989): No Protection

The economic advantages of an engineered retreat are less ambiguous. Even if the costs of raising the island are much less than we assume, retreat would further reduce the sand costs. Nevertheless, to maintain the harmony of the community, it would probably be reasonable to forgo these potential savings, at least for the next few decades.

To put these costs into perspective, consider the consensus projection in which sea level rises one

meter worldwide (and hence about 4 feet in New Jersey) by the year 2100, and the decision facing the community as shown in Table 4. In the year 2013, the sea has risen 6 inches since 1986, and can be expected to rise another 6 inches in the next 18 years. The cost of holding back the sea works out to $\$ 219$ per household; the cost of retreat would be about $\$ 30,000$ for every house moved or $\$ 77$ per taxpaying household. Regardless of whether the community or the relocating property owners pay for the retreat, it is difficult to envision a local government choosing to pursue such an option.

Picture the public hearings that might take place on the island. Both the ocean front and bay front

property owners would strongly advocate the status quo, which is most closely approximated by island raising. The citizens with the most to gain from a retreat, those whose houses would become ocean front, would be ambivalent because retreat would provide them with only a temporary oceanfront location, followed by the same disruption their next-door neighbors were currently facing. The majority in the middle would always prefer lower taxes. But with sea level rise a new experience, and with the hope that maybe it is not as bad as predicted, it is hard to imagine how a \$150 tax savings would motivate them to actively advocate that proven beach nourishment be disregarded so that a novel land-use scheme can be applied. 
The situation may change, however, as the rate of sea level rise accelerates. As Table 4 shows, by 2078 the annual savings from retreat could increase to $\$ 750$ per taxpayer, both because sand would be more expensive and the sea would be rising more rapidly. After two generations of sea level rise, retreating shorelines would no longer offend common sense. Moreover, our calculations may understate the potential for costs to accelerate. If Long Beach Island held back the sea while adjacent Island Beach State Park and Brigantine National Wildlife Refuge retreated, Long Beach Island would be like a headland, and experience greater alongshore losses of sand. The lag between sea level rise and erosion also implies that sand requirements in later years are greater than in early years even if the rate of sea level rise is constant. Thus, it seems reasonable to conclude that eventually the community would find a way to take advantage of the savings offered by an engineered retreat.

Table 4

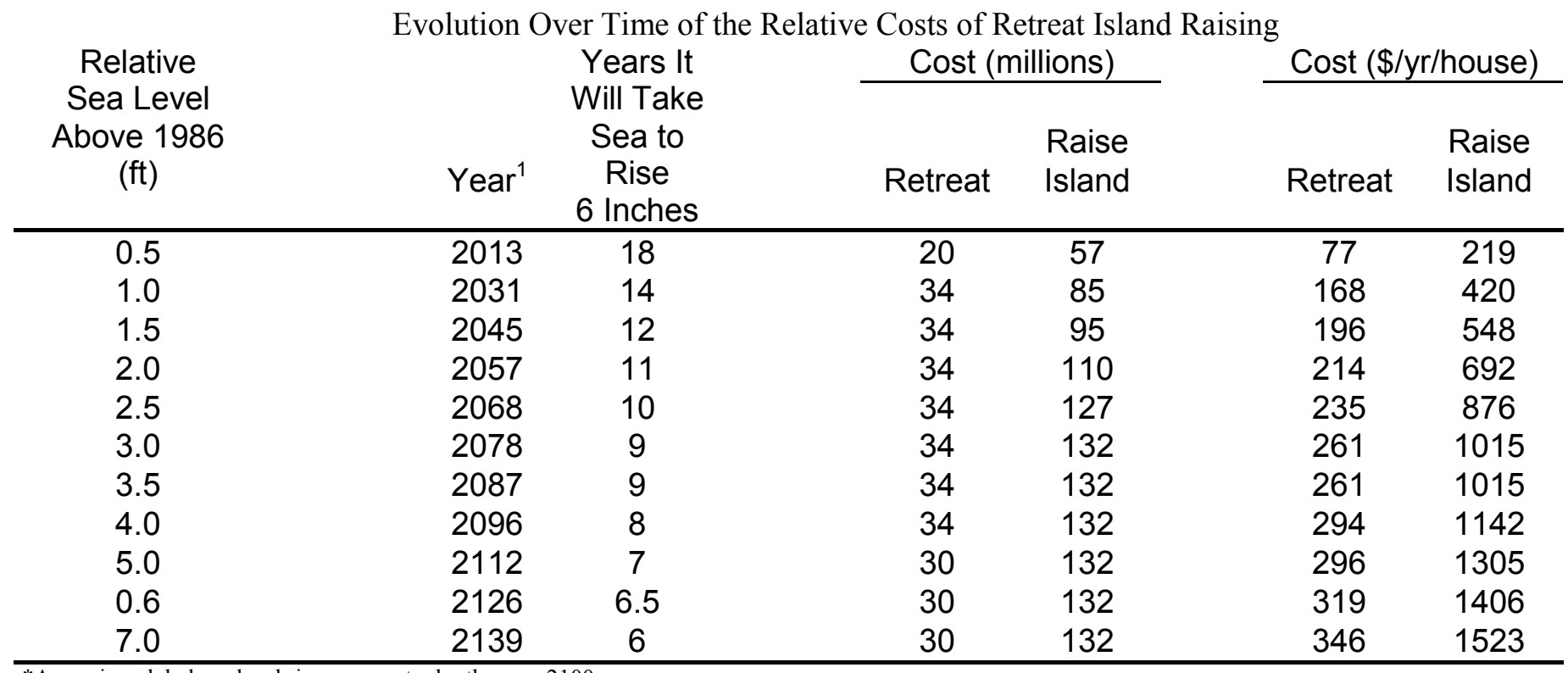

*Assuming global sea level rises one meter by the year 2100 .

NOTE: All costs assume that until the particular year, the community has responded to sea level rise by raising the island in place.

\section{Variations of the Theme}

Although our analysis of Long Beach Island is illustrative, one should not take the conclusions too seriously. Our cost calculations are based on rough rules of thumb whose reliability over long periods of time and large rises in sea level has not been tested. Moreover, we have ignored the possibility that a technological breakthrough would dramatically reduce costs of holding back the sea.

On the demand side, we have assumed that people's tastes do not change. Can we be sure that the popularity of barrier islands--and hence property values--will not fade to the level that prevailed before World War II? If future generations have less interest in suntans or greater interest in international travel; if coastal waters become polluted or invaded by jellyfish; or if rivers and lakes are cleaned up and hence become better sources of recreation, fewer people may desire buying or renting property on barrier islands.

Within the limitation of how we view the world today, we now examine variations from the Long Beach Island case study, considering differences in environmental conditions and economic development, as well as possible implications of other effects of global warming. 


\section{Differences in Environmental Conditions}

The shape of an island, the availability of sand, and the climate all influence the response to sea level rise. Because relatively little land is protected for each mile of shoreline protected, narrow islands like Long Beach Island are particularly unsuited for levees. The perimeter of an island with the same length but ten times the width would be only 15 percent greater, so a levee would only cost about 15 percent more; by contrast, the area that had to be raised would be ten times as great. Moreover, on wide islands, fewer people have a waterfront view in the first place, so the aesthetic problems with levees are less.

Beach nourishment costs depend on unit cost of sand and on how much is required. The unit cost varies throughout the coast because labor costs vary and some areas have high-quality deposits closer to the shore than others. Leatherman (1989) found a two- to- threefold variation in unit costs, which could be great enough to tip the balance between island raising and retreat.

Wave climate has a major impact on costs. By definition, sand requirements depend on the length of the beach profile; high energy waves generally imply longer profiles. Thus, barrier islands in Long Island Sound such as Fairfield, Connecticut, would have smaller requirements, which would tend to favor island raising. A rougher wave climate would tend to favor retreat and possibly abandonment; the gradual retreat along the Outer Banks is an example of the former case while the absence of development on Mississippi's hurricane-prone islands illustrates the latter.

Climate also influences the desirability of levees. The cost of a drainage system is roughly proportional to the amount of water that must be stored and pumped out during and after a major storm. In the case of Long Beach Island, the drainage system designed for 6.8 inches in 24 hours would account for only about 25 percent of the protection costs (Weggel et al. 1988). However, some areas in Florida can experience 12 inches in only 12 hours, and hence would require a much more costly system. ${ }^{18}$

\section{Development}

The level and type of development determine the ability of a community to economically justify protection, the logistics of island-raising and retreat, and the aesthetics of levees. Given the economics of shore protection at Long Beach Island, there is little doubt that such densely developed islands as Miami Beach; Ocean City, Maryland; and Galveston could justify protection for almost any conceivable rate of sea level rise or unit cost of sand. On the other hand, lightly developed areas such as the Outer Banks, or Holly Beach in Louisiana would have a difficult time raising the necessary funds.

Island raising is most suited to cases where structures are already on pilings well above the flood level; thus, newly developed islands such as Hilton Head would be easier to elevate than older areas such as Long Beach Island and Asbury Park, N.J., where most houses were built before 1968. Nevertheless, as storms, economic development, and old age lead existing houses to be replaced, the logistics will become more favorable. Although high-rises could not be easily elevated, they could be remodeled so that today's second floor becomes the new ground floor. Retreat would probably not work for islands where the oceanfront is populated with hotels and condominiums; on the other hand, it would be especially suitable for lightly developed islands with little infrastructure.

Although we have assumed that Long Beach Island and similar coastal barriers would view levees as a last resort (for lost resorts), people on urbanized islands would probably have fewer objections. Buildings already block much of the waterfront view, and recreation is a smaller part of the total scope of activity on such islands. Moreover, cities that combine commerce with recreation--such as Atlantic City-often have elevated boardwalks anyway.

\section{Other Impacts of Climate Change}

Four other impacts of global warming could influence future shore protection strategies: warmer temperatures, increased rainfall, increased storm severity, and the need to decrease emissions of greenhouse gases. Warmer temperatures would hurt Miami Beach because the portion of summer during which it is unpleasantly hot would be longer, and because resorts in northern Florida and adjacent states would be better able to compete with it during the spring and fall, and eventually winter as well. By 
contrast, beaches in Maine, New Hampshire and Massachusetts would become more popular because the water would be warm enough for swimming. The tourist seasons in the middle-Atlantic would be longer, and hotter summers would more frequently put people in the mood to escape the city for the relatively cool barrier islands. More revenue for resorts would tend to favor all forms of protection; given our assumption that island raising is preferred over retreat as long as it is affordable, higher property values would increase the likelihood of the former option.

An increase in hurricanes and other severe storms, on the other hand, would tend to favor retreat. Because the length of the beach profile depends on storm severity, more storms would increase sand requirements for holding back the sea. Increased rainfall would increase the cost of levee systems.

The need to curtail emissions of greenhouse gases may increase energy prices or make energy conservation an overriding policy goal, and thereby shift the relative advantages of various options. All of the options would have high energy costs: Abandonment would require increased commuting; levees would require pumping; and raising islands and engineered retreat would require substantial amounts of energy to move the sand.

\section{When Will a Response Be Necessary?}

The urgency of initiating a response depends on how a community intends to respond. Those that intend to employ levee systems have little reason to do anything today toward erecting a system that will not be necessary for fifty years. Because beach nourishment can be employed incrementally, there is no reason to begin placing sand on beaches that are not yet eroding, although some consideration may be worthwhile during the routine reconstruction of drainage systems (Titus et al. 1987) and roads.

By contrast, if an island is likely to retreat, the necessary institutional changes should be implemented today. If current assumptions about the rights of property ownership still prevail 75 years hence, it will be as difficult to move people from the ocean to the bay side then as it would be today. But suppose that the "rules of the game" were changed today, effective in 2065. By the time island raising became prohibitively expensive, everyone on the island would recognize the migration as a necessary inconvenience. The conceptually simplest approach would be to modify the deeds of all property owners to indicate that newly formed land on the bay side would accrue to the ocean front owner whenever the ocean shore eroded enough to necessitate relocation. Provided that such a condition was not effective for 75-100 years, the current impact on the market value of bayfront property would be negligible, and hence would probably not be construed by courts as a taking; even if it was, the fair market value of such a change would be negligible.

If a community is uncertain whether a retreat will be necessary, it would be rational to implement this institutional change as a way of keeping options open. If the sea does not rise appreciably, or if the community chooses to hold back the sea, the deed modification will have no impact because the ocean side will not erode enough to trigger it. This approach can be viewed as free insurance: if a retreat is unnecessary, the provision costs nothing; if retreat is necessary, the groundwork has been laid. But the longer communities wait before implementing such measures, the more they will have to delay the effective date to avoid court challenges.

At the nation's first conference on responses to future sea level rise, the developer of Hilton Head, South Carolina argued that it would probably take a hurricane to motivate people to take sea level rise seriously (Fraser 1984). In response, we explored some of the decisions facing barrier island communities after a hypothetical storm in 1990, using Sullivans Island, S.C. as an example (Titus 1984). That study concluded that people would rebuild if they could depend on government subsidies; given expected sea level rise, however, many people on Sullivans Island would not rebuild if they had to bear all the risks. As this article went to press, Hurricane Hugo devastated this and nearby barrier islands, focussing public attention on many of the issues addressed in this and the previous article.

South Carolina law prohibits much of the reconstruction that would otherwise take place on these islands. As one would expect, property owners are challenging the law's constitutionality because, simply 
put, the law will hurt their pocketbooks more than the storm. Proponents of the current law, however, argue that because the public must pay for storm damages, it has a right to limit construction in hazardous areas. ${ }^{19}$

The Catch-22 is that there is no way for property owners to give back the subsidy in return for the right to rebuild that is being sacrificed on account of that subsidy. Federal legislation, for example, prevents the flood insurance program from raising premiums to reflect the risk. Our institutions have provided liberal benefits to coastal property owners; now that the public sees them as overly generous, it seems easier to narrow constitutional rights than to revoke federally-approved subsidies.

Regardless of how South Carolina resolves the conflict, we hope that coastal communities can find a compromise that ends subsidies but protects property rights. In our view, states should be reasonably liberal about where people can build, but (1) deny flood insurance until rates are actuarially sound and (2) require houses to be removed when the beach narrows to a critical width. Such an approach would protect the environment and give shorefront residents an incentive to support higher flood-insurance rates; it would also transfer the onus of beach nourishment from the state to the local beneficiaries of these projects.

We recognize that the reader may disagree with one or more of the options this paper has presented. But we hope that all parties can agree that a rational response is most likely if there is a full and open debate on all the options and their implications. We have now reached the point where every barrierisland mayor and councilmember should have an opinion about how to respond to future sea level rise, and where every coastal town should hold public meetings and begin to develop a consensus on how to live with a rising sea on a warmer planet.

\section{Notes}

1. The opinions expressed in this article do not necessarily represent official views of the U.S. Environmental Protection Agency.

2. Reduced drainage would result from higher water tables having less storage capacity, as well as reduced hydraulic head, that is a reduced difference between the elevations of the area being drained and the level of the sea to which the water flows.

3. We assume that the property owners on the island will pay for most of the protection costs and are responsible for deciding which course to take, subject to federal and state law. Although state and federal governments have funded most coastal protection in the past, economic theory shows that subsidies usually promote economically inefficient investment, and there is a general trend away from subsidies for coastal protection. The substantial costs of holding back the sea, the increasing portion of decision makers with some background in economics, and the public perception that it is unreasonable for taxpayers to subsidize relatively affluent homeowners seem likely to further this trend.

4. These setbacks still use current erosion rates. However, maine's dune rules explicitly state that houses must be moved if sea level rises; they also require demolition plans for large buildings that would interfere with dunes or wetlands if sea level rises 3 feet.

5. The ongoing debate about the future of barrier islands in South Carolina is the first real test of this policy.

6. Because premiums from the coastal zone have been greater than claims in most years, other coastal residents, not taxpayers, have borne the cost of flood damages. However, a storm that devastated a large part of the coast could exhaust the program's resources and require a federal bailout. THe recent UptonJones Amendment of the Flood Insurance Act seeks to limit future claims by paying people to move or abandon ocean front houses. However, the new program may be inadvertently sending property owners the signal that the federal government will assume the risk of oceanfront development --particularly given the statutory rate cap that prevents the program from charging a fair-market price for insurance. 
7. The Coastal Barrier Resources Act, which denies federal aid to most Gulf and Atlantic shores not developed before 1982 costorm-damaged areas as "undeveloped" and hence deny flood insurance and other federal amenities to such areas. It is unlikely, however, that courts would allow the Secretary to apply this provision to the entire U.S. coast as sea level rises.

8. From the perspective of the Bruun Rule, the beach profile extends all the way across the island; compared with and eroding cliff, there is both a longer horizontal dimension to the profile and a smaller vertical dimension. Hence, the profile is much flatter for a barrier island, which implies a greater retreat of the shoreline in the Bruun formulation.

9. Early beach nourishment projects often used material from a back bay or an inlet, often in coordination with a navigation project. However, from the standpoint of sea level rise, dredging back bays is counterproductive since sea level rise will already be deepening them; moreover, with the increased amounts of sand necessitated by sea level rise, navigation will supply a decreasing fraction of total requirements.

10. The width of the island determines whether abandonment or retreat would have the worst impact on narrowing the estuary. Engineered retreat implies that the estuary will be narrowed right from the start, at the rate of ocean-side erosion. Abandonment implies that eventually the estuary will be narrowed at the more rapid overwash rate of inland migration, but only after the island has narrowed enough to begin to washover.

11. EPA's Atlanta office indicates that in some southeastern states, newly created land would belong to the public. They argue that in these states, the public would probably object to this land being sold to displaced oceanfront owners, preferring instead that it be kept undeveloped. Although officials in these states would have to weigh this consideration against the potential economic, environmental, and safety problems associated with other options, this situation would make engineered retreat easier than in areas where property accrues to bayfront owners, since governments would not have to negotiate the purchase the new lots.

12. Elsewhere, we discuss this approach in more detail for enabling wetlands to migrate inland. See Titus $(1986,1990)$.

13. Because fine sand that washes away is generally found in deposits of suitable sand, one must generally assume an overfill factor. For example, if half the sand is likely to wash away, the project must be designed based on twice the amount of sand necessary if one merely multiplied the area of the beach profile by the rise in sea level.

14. Wetlands would be inundated and bays would become deeper with an engineered retreat as well, but only in the beginning. COnsider an island that would erode 300 feet for every foot of sea level rise, with a bay 3 feet deep and 3000 feet wide, and a lowland slope of 0.3 percent. By the time the sea rises 10 feet, the barrier island would have migrated to the current mainland shore, and the new bay would occupy the current mainland, with depths distributed uniformly between 0 and 10 feet. Additional landward migration would keep the distribution of water depths roughly constant, as the system shifted landward. By contrast, if shores are stabilized, the entire estuary would be 13 feet deep, and as sea level rises it would continue to become deeper.

15. One can show that this assumption yields results equivalent to calculating shore retreat due the Bruun Rule, and then placing enough sand on the beach to counteract the erosion. We suggest, however, that people view the entire process simply ass "raising the profile" since that is 26 ntains a provision that allows the Secretary of Interior to designate $25 \mathrm{t}$ the environment and give shorefront residents an the net result and this formulation is more accurately conveys the relationship between the assumptions and the results.

16. National Geodetic Vertical Datum refers approximately to the mean sea level between 1910 and 1929. 
17. On islands with sea turtles or other important life along the dunes or the beach, one should assume a much larger buffer.

18. This level could be exceeded occasionally even in New Jersey. Because exceeding the design rainstorm merely implies that water will collect in the streets, it is reasonable to design for a storm severity that will, in fact be exceeded once in awhile. By contrast, exceeding the design wave could cause a catastrophic failure of the levee; hence, levees should be designed for very rare events. The Dutch, for example, have designed most of their sea dikes for the 10,000 year storm.

19. Actually, other coastal property owners, not the public at large, subsidize the risky development, since the flood insurance program is self-financing; but a federally-imposed private subsidy is no more efficient than a government subsidy.

\section{References}

Barth, M.C. and J.G. Titus, eds. 1984. Greenhouse Effect and Sea Level Rise: A Challenge for This Generation. New York: Van Nostrand Reinhold.

Bentley, C.R. 1983. "West Antarctic Ice Sheet: Diagnosis and Prognosis." In Proceedings: Carbon Dioxide Research Conference: Carbon Dioxide, Science, and Consensus. Conference 820970.

Bruun, P. 1962. "Sea Level Rise as a Cause if Shore Erosion." Journal of Waterways and Harbors Division (ASCE) 1:116-130.

Dean, R.G. (and 8 others). 1987. Responding to Changes in Sea Level. Washington, D.C.: National Academy Press.

Emmanuel, K.A. 1988. "The dependence of hurricane intensity on climate." Nature 326:483-85. Environmental Protection Agency. 1990. Policy Options to Stabilize Global Climate, Washington, D.C.: Government Printing Office.

Everts, C. H. 1985. "Effects of Sea Level Rise and Net Sand Volume Change on Shoreline Position at Ocean City, Maryland." In Potential Impacts of Sea Level Rise on the Breach at Ocean City, Maryland. Washington, D.C.: Environmental Protection Agency

Fraser, C. 1984. "Comment” In Barth and Titus, eds., op. cit.

Howard, J.D., O.H. Pilkey, and A. Kaufman. 1985. "Strategy for Beach Preservation Proposed." Geotimes 301215-19.

Hoffman, J.S., D. Keyes, and J. G. Titus. 1983. Projecting Future Sea Level Rise. Washington, D.C.: Government Printing Office.

Hughes, T. 1983. "The Stability of the West Antarctic Ice Sheet: What Has Happened and What Will Happen." In Proceedings: Carbon Dioxide Research Conference: Carbon Dioxide, Science, and

Consensus. Conference 820970. Washington, D.C.: Department of Energy. Hull, C.H.J. and J.G. Titus. eds. 1986. Greenhouse Effect, Sea Level Rise, and Salinity in the Delaware

Estuary. Washington, D.C.: Environmental Protection Agency and Delaware River Basin Commission.

Kana, T.W., J Michel, M.O. Hayes, and J.R. Jensen. 1984. "The Physical Impact of Sea Level Rise in the Area of Charleston, South Carolina." In: Barth and Titus eds. op. cit.

Kana, T.W., B.J. Baca, and M.L. Williams. 1988. "Charleston Case Study" . In Titus. ed., 1988 op. cit. Kana, T.W., W.C. Eiser, B.J. Baca, and M.L. Williams. 1988. "New Jersey Case Study." In Titus. ed. 1988. op. cit.

Lashof, D.A. 1989. "The Dynamic Greenhouse: Feedback Processes that May Influence Future Concentrations of Greenhouse Gases." Climatic Change 14:213-242.

Leatherman, S.P. (1989) "Nationwide Cost of Nourishing Recreational Beaches In Response to Sea Level Rise." In Smith and Tirpak, op cit. 
Leatherman, S.P. 1984. "Coastal Geomorphic Responses to Sea Level Rise: Galveston Bay, Texas." In: Barth and Titus (eds). op. cit.

Leatherman, S.P. 1979. "Migration of Assateague Island, Md. By Inlet and Overwash Processes," Geology 7:104-107.

Kyper, T. and R. Sorensen. 1985. "Potential Impacts of Selected Sea Level Rise Scenarios on the Beach and Coastal Works at Sea Bright, New Jersey. In Magoon, O.T., et al. (eds). Coastal Zone '85. New York: American Society of Civil Engineers.

Louisiana Wetland Protection Panel. 1987. Saving Louisiana's Wetlands. Washington, D.C.: Environmental Protection Agency.

National Academy of Sciences. 1979. CO2 and Climate: A Scientific Assessment. Washington, D.C.: National Academy Press.

National Academy of Sciences, Polar Research Board. 1985. Glaciers, Ice Sheets, and Sea Level. Washington, D.C.: National Academy Press.

Office of Coastal and Resource Management. 1989. "Shoreline Erosion: A Management Priority." Information Memorandum \#5. Washington, D.C.: National Oceanic and Atmospheric Administration.

Park, R.A., T.V. Armentano, and C.L. Cloonan. 1986. "Predicting the Effect of Sea Level Rise on Coastal Wetlands." In Effects of Changes in Stratospheric Ozone and Global Climate. Titus, J.G., Washington, D.C.: United Nations Environment Programme and U.S. Environmental Protection Agency.

Park, R.A., M.S. Trehan, P.W. Mausel, and R.C. Howe. 1989. "The Effects of Sea Level Rise on U.S. Coastal Wetlands." In Smith and Tirpak, op. cit.

National Academy of Sciences. 1983. Changing Climate. Washington, D.C.: National Academy Press.

Pilkey, O., and 7 others. 1982. Saving the American Beach: A Position Paper By Concerned Coastal Geologists. Savannah, GA: Skidaway Institute of Oceanography.

Ramanathan, V. R.J. Cicerone, H.B. Singh, and J.T. Kiehl. 1985. "Trace Gas Trends and their Potential Role in Climate Change." Journal of Geophysical Research 90:5557-5566.

Rind, D., Goldberg, and Ruedy. 1989. "Variability and the GISS Model." In Smith and Tirpak, op. cit.

Seidel, S. and D. Keyes. 1983. Can We Delay a Greenhouse Warming? Washington, D.C.: Environmental Protection Agency.

Schneider, S. and R.S, Chen. 1980. "Carbon Dioxide Flooding: Physical Factors and Climatic Impact." Annual Review of Energy 5:107-140.

Smith, J. and D. Tirpak (eds). 1989. The Potential Effects of Global Climate Change on the United States. Washington, D.C.: Environmental Protection Agency.

Titus, J.G. "Strategies for Adapting to the Greenhouse Effect." Journal of the American Planning Association (in press).

Titus, J.G. 1989 "Options for Enabling Wetlands to Migrate Landward as Sea Level Rises." Draft. Washington, D.C.: Environmental Protection Agency.

Titus, J.G. (ed) 1988. Greenhouse Effect, Sea Level Rise, and Coastal Wetlands. Washington, D.C.: Environmental Protection Agency.

Titus, J.G. 1986. "Greenhouse Effect, Sea Level Rise, and Coastal Zone Management." Coastal Management 14:3.

Titus, J.G. 1984. "Planning for Sea Level RiseAlong Sheltered Waters of the United States." In Smith and Tirpak, op. cit. 
Titus, J.G., C.Y.Kuo, M.J. Gibbs, T.B. LaRoche, M.K. Webb, and J.O. Waddell. 1987. "Greenhouse Effect, Sea Level Rise, and Coastal Drainage Systems." Journal of Water Resources Planning and Management, 113(2):216-227.

Weggel, R., S. Brown, and E. Doheny. 1989. "The Cost of Defending Developed Shorelines Along Sheltered Waters of the United States." In Smith and Tirpak, eds., op.cit.

Wilcoxen, P.J. 1986. "Coastal Erosion and Sea Level Rise: Implications for Ocean Beach and San Francisco's Westside Transport Project." Coastal Management 14:3: 173-191.

Williams, P. 1989. "The Impacts of Climate Change on the Salinity of San Francisco Bay." In Potential Impacts of Climate Change in the United States, ed. J. Smith and D. Tirpak. eds. Washington, D.C.: Environmental Protection Agency.

Yohe, G. (1989) "The Cost of Not Holding Back the Sea." Draft submitted to Journal of Ocean and Shoreline Management Before and After a Coastal Disaster." 